DOI: http://dx.doi.org/10.24818/jamis.2019.04004

\title{
Determining factors of the quality of joint audit: Tunisian context
}

\author{
Lassaad Abdelmoula ${ }^{\mathrm{a}, 1}$ and Habib Affes ${ }^{\mathrm{a}}$ \\ ${ }^{a}$ Faculty of Economics and Management of Sfax, Tunisia
}

\begin{abstract}
Research question: Identify the significant determinants of the quality of joint audit in the context of Tunisian companies. Motivation: Few studies have been conducted on the determinants of the quality of the joint audit in the Tunisian context. Thus, our study aimed to fill this gap. Idea: Our study aimed to fill this gap by studying Determining factors of joint auditors' job quality in the Tunisian context. Data: Our methodology was applied to 222 Tunisian companies, 108 of which belong to the banking sector, 67 to the insurance sector, 28 whose commitment exceeds 25 billion dinars and 19 company having a consolidated balance sheet total of over 100 billion dinars. Tools: A "factorial analysis" was carried out followed by an "internal coherence" test. Then, a logistic regression, which enabled us to test the impact of each determining factor on the quality of the joint audit, was carried out. Findings: This study emphasizes the participation of several factors that enhance the quality of the joint audit. According to the predictive results of our model, it seems that the quality of the joint audit contributes to the prediction of three factors, namely competence, independence and reputation. Contribution: Our findings contribute through a better understanding of the determinants of the joint audit in a Tunisian context.
\end{abstract}

Keywords: joint audit, competence, respect of ethical rules and due diligence, independence, reputation.

JEL codes: M40

\footnotetext{
${ }^{1}$ Corresponding author: Lassaad Abdelmoula, Department of Accounting, Faculty of Economics and Management of Sfax, Tunisia; tel. (+216)44571871, lassaad.abd86@ gmail.com
} 


\section{Introduction}

With the increasing impact of the global financial crisis questions have arisen concerning the quality and scope of the independent audit. Moreover, after Enron's scandal and the collapse of the Arthur Anderson Audit Institute, the major consideration was the threat of creating a monopoly. Supplementary Supervision has been required to improve the independence of auditors in order to restore confidence in the audited financial statements. In this context, several regulations aiming to restore investors' confidence in the audit were presented. The publication of the Green Paper, called Audit Policy, by the European Commission (EC) was one of the measures taken to improve the audit rules, the audit quality and also to create a competitive market. Regulatory approaches that aim at reinforcing market confidence in the independence of the auditor include joint audit, auditor's rotation, stressing the formation of the audit committee and limiting non-audit services. The objective of the joint audit is to support auditors' independence and enhance the services they provide. This is attainable if the joint auditors apportion audit work and charges so that each of them can fully and properly accomplish his or her role. During the audit mission, the joint auditors have to equitably use auditing tools. They also have to go over each other's work and provide a report on the full scope of the audit. Thus, only one audit report should be approved by the two auditors.

There is a consensus between researchers concerning the definition of Joint audit. For example, previous works by (Zerni et al., 2012; Baldauf \& Steckel, 2012; Ratzinger-Sakel et al., 2013) define joint audit as an audit in which two or more independent auditors, from distinct audit firms, are selected to audit the financial statements of a client. This is based on jointly preparing the audit plan and conducting the audit work. Furthermore, joint audit consists of making periodic cross-reviews and reciprocated quality controls, delivering and signing one common audit report and being responsible in the event of audit failure. It should be noted that the notion of joint audit is different from dual audit. In the latter, two or more independent auditors from distinct audit firms are assigned to audit financial statements of a client. In this type of audit, the audit plan is planned disjointedly, the audit work is carried out separately, there are no regular cross-reviews and no reciprocated quality controls. Moreover, different audit reports are issued by the different auditors each of whom is only responsible for the information in his own report (Ratzinger-Sakel et al., 2013; Jane lin et al., 2014). In addition, the notion of joint audit can be distinguished from that of Double Audit, in which the same auditor is required to complete the audit work twice (Ratzinger-Sakel et al., 2013).

To reduce market concentration, the EU resorts to the use of joint audits. In addition, there are countries that have already applied joint audits to increase auditor independence. In 1966, mandatory joint audit was implemented in France (Ratzingel-Sankel et al., 2013). At that time, this was a requirement for all firms that 
meet specific criteria. In 1984, the scope of mandatory joint audit extended to all firms that provide consolidated financial statements. According to the same authors, the mandatory joint audit has some practical implications including assigning tasks to auditor and agreeing on the methodology used (Ratzingel-Sankel et al., 2013). Overtime, France established several standards to address these implications. For example, it is compulsory that the statutory auditors first approve the audit procedures chosen to implement the audit plan. Furthermore, the audit tasks are shared among auditors taking into account the quality and quantity of the auditors. Eventually, when the different auditors hold different points of view, they can issue different reports.

Joint audit was also implemented in Denmark for listed companies in 1930. Unlike France, Denmark did not postulate how the joint audit work should be conducted. This may lead to inefficient teamwork and thus to higher audit costs (Holm \& Thinggaard, 2014). In 2001, Denmark suggested the abolition of mandated joint audit after 2004. This decision was due to many reasons. For instance, the parliament of Denmark claimed that joint audits entail 'unnecessary high audit costs'. Furthermore, the global market accepts the fact that firms are audited by a single audit. The increased additional overhead of joint audits compared with singular audits is thus redundant according to Danish authorities. Furthermore, they assume that singular audits can be achieved based on a more general approach. As a result, Danish firms no longer have to get their financial statements audited by joint auditors. However, joint audit is still allowed on a voluntary basis only.

In Sweden, joint audit was mandatory only for banks and insurance firms respectively until 2006 and 2010. The Swedish financial authority was not obliged after 2006 to appoint a second auditor to banks. However, it can assign a second auditor to banks and insurance firms in certain situations. It is worth noting that the Swedish financial authority rarely avails itself of this right (Ratzingel-Sakel et al., 2013).

After the failure of the Home Bank in 1923 that influenced more than 60,000 clients, mandatory joint audit was implemented in Canada. This implementation aimed at reinforcing credibility about the loan portfolios of banks (Green, 2006). In more than 60 years, the first bank in Canada that has fallen due to failure was the Canadian Commercial Bank which stopped operating in 1985. Therefore, joint audit could not avoid this failure. In 1991, the Canadian Bank Act eliminated the mandatory joint audit and only permitted singular audit (Lew \& Richardson, 1991) as the costs of joint audit do not supersede its benefits. Unlike Denmark, voluntary joint audit is not permitted in Canada. In many countries such as, Algeria, Congo, India, Ivory Coast, Germany, Kuwait, Morocco, Tunisia, Saudi Arabia, South Africa and Switzerland joint audits, either mandatory or not, have been implemented. 
Many researchers have been interested in examining the notion of joint audit. France and the Scandinavian countries have attracted much interest due to the fact that data concerning joint audit in these countries are comprehensive compared to other countries.

According to the Tunisian commercial code amended in 2005 (Tunisia, 2005, article13), joint audits are only necessary for listed banks, insurance companies, companies that prepare consolidated accounts as well as those with liabilities exceeding a certain limit. Regulation concerning joint audit in Tunisia seem to be inspired from the French regulations. Nevertheless, contrary to France, Tunisia has no laws that organize how work is shared among the two auditors.

Several research works have dealt with the subject of joint audit in Sweden (Zerni et al., 2012; Ittonen \& Trønnes, 2015), in Germany (Velte \& Azibi,2015), in France ( André et al., 2015; Loba et al., 2017; Haak et al., 2018), in Denmark (Holm \& Thinggaard, 2016; Lesage et al., 2017), in Egypt (Ghanem El Assy, 2015; Mandour \& Mokhtar, 2018), in Italy (Bisogno \& De Luca, 2016; Bianchi et al., 2019), and in Kuwait (Alfraih, 2016). However, there are only a few studies that were conducted about the Tunisian context and thus results from previous studies cannot be applied to this sector. In this context, our study aimed to fill this gap by studying Determining factors of co-statutory auditors' job quality: Tunisian context.

This study is relevant in many ways. Theoretically, it helps to show the importance received by joint audit mission in the recent economy and provide a review of a vast literature about the field of research on the determinants of the quality of the joint audit. From a practical point of view, our study will enable us to identify the significant determinants of the quality of the joint audit in the context of Tunisian companies. In order to meet the objective of our research, we adopted a particular methodology which aimed at emphasizing the most significant determining factors of the quality of the joint audit. Three essential determining factors were predicted; competence, independence and reputation. Our methodology was applied to 222 Tunisian companies, 108 of which belong to the banking sector, 67 to the insurance sector, 28whose commitment exceeds 25 billion dinars and 19 companies having a consolidated balance sheet total of over 100 billion dinars.

First, we began by emphasizing the most significant elements related to each determinant. For this reason, these items were introduced at the level of a questionnaire in order to identify the determining factors of the quality of the joint audit, which take into account the specificity of the Tunisian context. The respondents showed their attitude regarding the importance of the item by choosing a level (1-5) of a Likert scale (ordinal scale). When the answers were collected, a "factorial analysis" was carried out followed by an "internal coherence" test. Then, a logistic regression, which enabled us to test the impact of each determining factor on the quality of the joint audit, was carried out. The application of this methodology 
on the collected data for our sample showed that quality of the co-statutory auditors' job is predicted by three main factors, namely competence, independence and reputation.

However, our results showed the absence of a significant and positive relationship between compliance with the professional due diligence and the quality of the costatutory auditors' mission which is essentially caused by the choices of the items. Thus, other items would likely improve the measure of independence.

The remainder of the paper is organized as follows: first, a literature review is outlined to help derive the hypotheses to be tested. Then, the research methodology is presented and the results are discussed. Finally, we end with a conclusion in which we will try to underline the academic and managerial implications and the limitations of our work.

Previous works on joint audit highlight both its advantages and disadvantages. Arguments in support of mandatory or voluntary joint audit include increased confidence in the audit due to the fact that both parties have to agree on the audit before signing it (Mazars, 2010). Accordingly, the audit quality is boosted and failure is rare as it is carried out by two auditors (Bisogno \& De Luca, 2016).

Another advantage of joint audit is the rotation of auditor. This does not only sustain the neutrality essential for high quality audit but also preserves the knowledge and know-how of the audit (Mazars, 2010; Carcello \& Nagy, 2004). Moreover, joint audit develops the audit market and raise competition. For example, the Big 4 firms would not be able to overpower the market and this gives non-Big 4 firms more opportunities (Andrè et al., 2009; Mazars, 2010). However, according to Francis et al. (2009), the participation of a Big 4 or even two Big 4 firms enhances the audit quality. However, their absence in audit process leads to a lower degree of audit quality. According to Mazars (2010), this situation may be beneficial as non-Big 4 firms can gain competence and thus contribute to the market by providing a wider range of qualified auditors. In addition, joint audit is a strong mechanism to fight bribery and resist pressure from the management as joint auditors can force the managers to participate in informal discussions to reach their objectives (Zerni et al., 2012). Other studies claim that joint audit reinforces auditors' independence, which is a determining factor of quality (Carcello \& Nagy, 2004; Zerni et al., 2012).

However, opponents of joint audit highlight the menace of free-rider problems as one of the auditors might overlook his work and draw on the other auditor to do the whole work (Neveling, 2007). In the same vein, Francis et al. (2009) claim that a couple of two Big 4 firms and a couple composed of one Big 4 firm and one nonBig 4 firm are more likely to be exposed to the problem of free-rider. Moreover, the audit firms are embroiled in a contestation as they are obliged to collaborate despite 
their shared competitive position. This situation leads to low quality audit. Information exchange may be overlooked according to Neveling (2007) which has a negative impact on joint audit. Finally, the same author points to the deficiencies of the accounting standards themselves that can be interpreted differently. Consequently, this can lead to many conflicts and reduce cooperation between the auditors.

\section{Literature review}

In this first part, we start with the presentation of the theoretical framework used in this research. Then, in the next part, we introduce the previous research that dealt with our problem in order to identify the determining factors of the quality of the joint audit and formulate the hypotheses to be tested.

\subsection{Theoretical framework}

The research field of this study involves the checking, the audit and the statutory audit. The theories that govern it are the positive agency theory and, particularly, the contractual and the delegation theory. The positive agency theory starts from the hypothesis of the conflicts of interests between the different parties involved in the entity, mainly the principal and the agent or the owner and the manager. These two parties are bound by a contractual relationship of Agency, which is built upon an explicit or an implicit contract between the principal and the agent. The owner, who is unable to customize the entity, assigns part of his property rights to the agent in the form of intelligence delegation. The latter is found to be skillful at making decisions instead of the owner. His stewardship of the entity confers him a set of private information known only to him. This is known as information asymmetry (Charreaux, 2000).

Moreover, contracts at the beginning of this relationship are inherently incomplete. In fact, we cannot anticipate all the contingencies when these contracts are drafted. Guided by his opportunism, the agent tends to make the decisions for his benefit even if they were at the expense of the principal. To protect himself against this, the owner appoints an auditor and entrusts him with the control of the agent and the quality of his performance. As a result, the auditor finds his legitimacy in the separation between the owner and the manager and thus in the contractual agency theory (Charreaux, 2000).

\subsection{Competence}

Competence is the initial characteristic of the auditor's behavior during a Statutory Auditing mission. In the mind of the legislator, it tends to promote knowledge based, first and foremost, on education (Flint, 1988; Manita \& Elommal, 2010) embodied 
by the notion of formal knowledge (Everaere, 2000) and second, on the know-how defined by Flint (1988) as the product of experience.

The competence of joint auditors is one of the major determinants of his quality. However, one may wonder how the principal can appreciate the knowledge of each co-statutory auditor: it is by having a chartered accountant diploma or through professional experience. Moreover, expertise and experience are the primary principles of jurisdiction. The statutory auditor is a person who has knowledge that gives him the title of an expert. In this regard, expertise is the process of accumulation of knowledge that ensures the passage from knowledge (a set of theoretical knowledge) to know-how (realization). This type of knowledge is born from experience, which is considered the first element of expertise. The impact of experience is related to the statutory auditor's behavior in a particular situation.

Lee and Stone (1995) and Octavia and Widodo (2015) showed the impact of the process of knowledge accumulation on the auditor's independence. A novice auditor should not only rely on the standards, rules and principles governing the profession, but also on the arguments put forward by the client. This attitude has an adverse effect on his independence; however, it diminishes as he acquires experience.

Bonner and Lewis (1990) and Rusmanto (2016) studied the criteria that explain the difference in the performance of auditors. They used measures, such as knowledge and skills borrowed from psychology. They identified three determinants of expertise of basic and general knowledge held by any professional accountant, which seems to be the result of the training of the auditor, the specific knowledge of an activity sector as well as knowledge about the contractual relations and the business.

In this context, we tried to identify the relationship between the satisfaction of clients' expectation and the quality of the offered service (Baker, 1994) and mainly the competence of the employees. Indeed, the term competence is taken here in a broad meaning, as relational (reactivity), technical (disciplinarity) and organizational knowledge (having a comprehensive approach in solving problems).

Some researchers inferred that specialization in a particular sector enhances progress. They found that specialized firms achieve cost savings on their audit assignments and at the same time give a better audit quality thanks to their knowledge of the business sector (Hogan \& Jeter, 1999; Khaddash et al., 2013).

The consulting service for the audited client may be considered as a threat to the statutory auditor's independence. By carrying out the board's tasks, an auditor will have some kind of economic dependence on his client. If the fees pertaining to the board's mission are significant, the auditor's economic dependence may create a bias in his/her judgment and lead to a loss of impartiality and objectivity (Wines, 1994; Read, 2015). However, some authors (notably Abdel-Khalik, 1990) assume that the audit firm's mission can be beneficial for the audit insofar as it leads to the 
improvement of the auditor's knowledge of his client, which subsequently improves the audit quality.

Furthermore, the use of information and communication technologies (ICT) is a determinant of competence. In fact, professional accountants seek ways to improve all the stages of work and improve the quality of the service. In this sense, Lin et al. (1993) concluded that Information Technology (IT) is a means to improve auditors' performance. They refer to the word processing software, spreadsheets and statistical sampling software as applications that help accomplish the statutory auditor's work. Therefore, they ensure cost reduction and the updating of the work papers from which they keep security copies.

Some authors (for example, Baldauf \& Steckel, 2012) claim that Joint Audit may ameliorate auditor competence through preserving knowledge acquired from auditors' meetings (Guo et al., 2017). Another benefit of joint audit is the rotation of auditor. This does not only sustain the neutrality which is essential for high quality audit but also preserves the knowledge and know-how of the audit (Carcello \& Nagy, 2004; Holm \& Thinggaard, 2017). This question has led the European Commission, in its Green Paper issued in 2010, to propose several mechanisms that can be used to reinforce both auditors' abilities to spot material inaccuracies in financial statements and also their stimuli to report these identified material inaccuracies (Lobo et al., 2013; Lobo et al., 2017)).

According to DeAngelo's (1981) audit quality encompasses two components, namely competence and independence. Thus, joint audits could be expected to influence both components. From the point of view of competence, a probable lack of experience of the auditor at the beginning of a mission (e.g., Carey \& Simnett, 2006) can be alleviated in the context of joint audit if the rotation of the assigned audit firms does not occur at the same time (Lesage et al.2017). Joint audits should assure auditor rotation in order to circumvent the discontinuity in terms of knowledge of business operations (Carcello \& Nagy, 2004; Bisogno \& Luca, 2016; André et al., 2016).

Hence the first hypothesis is presented as follows:

H1: The executive directors of the co-statutory auditors assess the quality of the joint audit through the competence of each auditors.

\subsection{Respect of ethical rules and due diligence}

Al qtaish et al. (2014) defined eight ethical rules, namely honesty and integrity, professional efficiency, confidentiality of information, professional conduct and care, independence, contingent fees, commissions and advertising. The results show that these rules have a significant effect on audit quality. 
Manita and Elommal (2010) showed that due diligence has a significant impact on audit quality. Thus, our second hypothesis is as follows.

H2: The clients of joint auditors appreciate the compliance with the ethical conduct and professional due diligence by each of auditor.

\subsection{Independence}

The independence of each of the co-statutory auditors, which is one of the basics of the profession, has been the subject of several definitions. Watts and Zimmermann (1981) and Manita and Elommal (2010) stated that independence reflects the auditor's ability to withstand the pressures of the company's managers. Moreover, Bazerman et al. (1997) as well as Wamba and Tagne (2014) concluded that an auditor is independent when he is able to make objective and free judgments detached from the influence of his client.

In this sense, items such as the effect of seniority in the office and the provision of services outside the statutory audit by the network affect the relationship of each auditors with the audited entity. The former, i.e. the duration of the mandate, constitutes a significant determinant with a twofold effect. First, a close relationship is created between the in-charge of the mission and the client, which implies a negative effect on independence (Mautz \& Sharaf, 1961; Mousa, 2015). However, the provision of non-statutory auditor services by the network is one of the main sources of conflicts of interest between the statutory auditor and the audited entity, which is linked to the interests of all the stakeholders. In fact, this case is likely to arise when the statutory auditor holds personal, professional, financial or family interests within the audited entity. Moreover, Koh and Mahathevan (1993) and Brahima and Abdelkadera (2014) devoted their studies to the perception of an independent auditor hired by his client. The results showed that the shorter the time between the occupancy of both positions, the more the independence is affected when an ex-auditor accepts the position of a preparer after having delivered a favorable opinion about the accounts.

At the same time, the items that affect the relationship between the two statutory auditors are the work repartition and size asymmetry between them. Regarding the first part, it was found that the code of ethics promotes a balanced distribution of the work program between the co-statutory auditors and a reciprocal review of the files. The work program is designed according to the specific means and competences of each auditor.

It is obvious for the joint auditors to prove together the planning and the organization of their work. In all cases, they should take into account the technical means and the particular competences of each of them. The second option consists in specifying 
two audit firms that do not have the same size. This means that it happens that a "big 4" firm can be a joint auditors with a small-sized audit firm.

Bennecib (2004) states that when there is a very strong asymmetry between two firms charged with a mission, the small firm, which does not have similar technical and human means, conducts an important part of the work. The distribution can reach a proportion of 20/80 between both auditors; however, two firms of the same size will share the work equally.

Previous works state that auditors in a joint audit are more independent. This is an indicator of the high quality (Zerni et al., 2012; Velte, 2017). Joint audit may enhance auditor independence by lowering the economic relationship between the auditor and the client as joint auditors share audit fees between them.

Nevertheless, Deng et al. (2012) claimed that joint audits may weaken auditor independence as they give clients the opportunity for opinion shopping (Al-Hadi et al., 2017). In the Egyptian context, Khatab (2013) investigated whether joint audit influences firm value and auditor independence, as proxies for audit quality based on a sample of 34 companies listed on the Egyptian Stock Exchange during the period between 2005 and 2009. The author showed that joint audit does not influence firm value or auditor independence (Okaro et al., 2018).

The third hypothesis is as follows:

H3: The agents of the joint auditors base their assessment of the quality of the joint audit on the independence of each auditors.

\subsection{Reputation}

Reputation plays the role of the regulator in favor of independence. According to Richard (2000), the objective of the auditor is to be chosen by the shareholders and then to maximize his profits. Kreps (1990) concluded that a specialist's confidence is built depending on reputation, which is itself based on how the previous missions were accomplished. As a consequence, a statutory auditor whose name is not mentioned in connection with financial scandals or fraudulent business has a good reputation. Nevertheless, the auditors who do not report bad manipulations of the accounts damage their reputation (Watts \& Zimmerman, 1983; Firth, 1997; Dedman et al., 2014; Joshi et al., 2014).

The works of De Angelo (1981) and Naslmosavi et al. (2013) showed that the quality of the service delivery depends on the size of the audit firm. They also stated that large firms possess technology and have competences that distinguish them from other audit firms, which makes them more famous. This helps them not only to attract clients, but also to retain them. They also concluded that the larger the audit firm is (measured by the number of clients), the less opportunistic the auditor's behavior and the better the quality of the perceived service delivery is. 
Moreover, the audit firm's reputation is also based on the fees it receives. Craswell et al. (1995) and Yaşar (2013) assume that the most famous auditors, particularly the Big4, receive the highest fees. These studies, along with those of Krishnamurthy et al. (2003) and Skinner and Srinivasan (2012) who found that reputation (measured by the audit firm's size) is based on the perception of the quality of the service delivery. De Angelo (1981) says that large firms (international firms) ensure the quality of their service delivery. Similarly, Defond and Jiambalvo (1993) and Kwon et al. (2014) stipulate that these firms spend huge costs to develop a good reputation and are more likely to know the irregularities and fraud. In fact, St Pierre and Anderson (1984) noticed that the Big4 firms are less subject to legal proceedings, which positively affects the service quality.

Marmousez (2012) analyzed how corporate governance mechanisms influence the decision to choose zero Big 4, one Big 4 (paired with a non-Big 4) or two Big 4 auditors. The findings of this work concerning why two Big 4 auditors should be chosen are particularly interesting. Smaller client companies were found to have no motivation to choose two Big 4 auditors. For medium-sized companies, the presence of an audit committee is positively linked to the choice of two Big 4 auditors. Bigger companies, for their part, were all found to select at least one Big 4 auditor, as their large size and international scope generally urge them to select two Big 4 audit firms (Kermiche \& Piot, 2016).

Francis et al. (2009) showed that firms audited by two Big 4 audit firms have lower abnormal in come-increasing accruals (used as a proxy for audit quality) than companies audited by one Big 4 and one non-Big 4 audit firm. They found that companies with higher agency costs, which include costs for negotiating information asymmetries, are more likely to be audited by higher-quality audit pairs (two Big 4 firms). Big 4-Big 4 pairs therefore produce the highest quality audits, followed by auditor pairs of one Big 4 and one non-Big 4. Furthermore, the authors concluded that companies with higher agency costs are more likely to be audited by those auditor pairs, and to have higher-quality earnings (Mandour \& Elharidy, 2018). According to Deng et al. (2012), a joint audit may result in less audit costs, especially when there is a small difference between the two auditing companies in terms of technology or when big audit firms are in charge for most of the audit work (Holm \& Thinggaard, 2017).

Hence the fourth hypothesis:

H4: The agents of the joint auditors assess the quality of the joint audit by referring to the reputation of each auditors. 
Our model is summarized in figure 1:

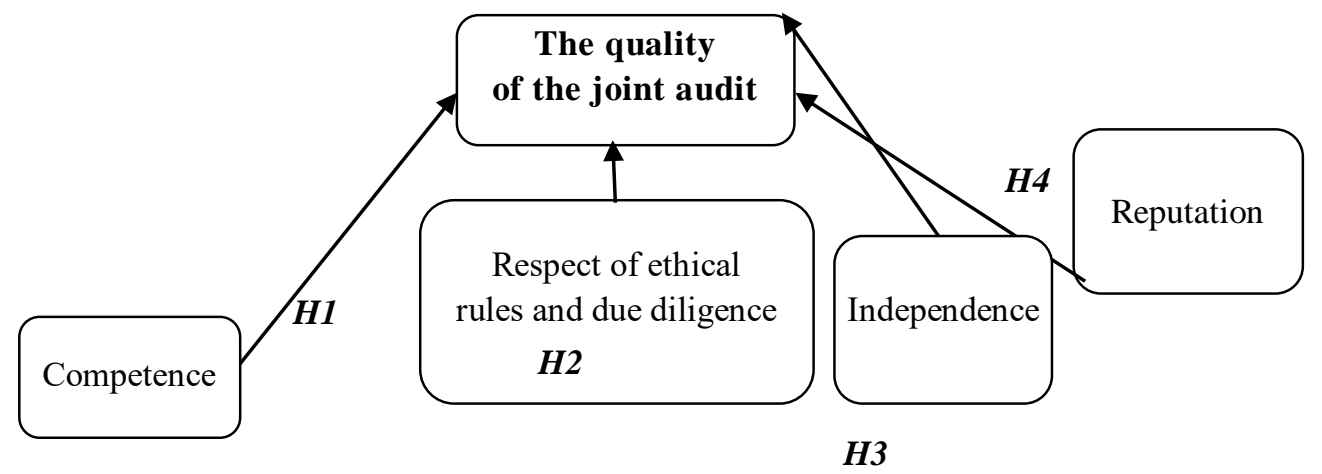

Figure 1. The determinants of the quality of the Joint audit

\section{Methodology}

We start with a description of our sample, then, we clarify the method adopted for data collection. Finally, we present the method of the data analysis.

\subsection{The sample}

The study of the representativeness of our sample should assess the effects related to the determinants of the quality of the joint audit and the sampling errors. In fact, out of 222 companies obtained, 288 were selected on the basis of criteria; the activity sector. Regarding the gap between the target population and the sampling frame from which the sample is drawn, the most important bias source shows that our sample consists of banks and insurance companies only. Moreover, our results may not be generalizable to all the Tunisian companies. Nevertheless, to correct this gap, we have included companies with commitments exceeding 25 billion dinars as well as companies with consolidated balance sheet totals exceeding 100 billion dinars. This should minimize the coverage error.

It should be noted that in terms of activity sector, our sample is more or less diversified as the companies considered in our sample belong to the various sectors of activity (Table 1). As can be seen in table 1, the existence of an imbalance within the sectors composing our sample depends on the specificity of the Tunisian context. 
Table 1. The sectors composing our sample depend on the specificity of the Tunisian context

\begin{tabular}{lcc}
\hline Business sector & Number & Percentage \\
\hline Bank & $\mathbf{1 0 8}$ & $\mathbf{4 8 . 6}$ \\
insurance industry & $\mathbf{6 7}$ & $\mathbf{3 0 . 1 8}$ \\
$\begin{array}{l}\text { companies the commitment of which exceeds 25 billion } \\
\text { dinars }\end{array}$ & $\mathbf{2 8}$ & $\mathbf{1 2 . 6}$ \\
$\begin{array}{l}\text { A company with a consolidated balance sheet total } \\
\text { exceeding 100 billion dinars }\end{array}$ & $\mathbf{1 9}$ & $\mathbf{8 . 5}$ \\
Total & $\mathbf{2 2 2}$ & $\mathbf{1 0 0}$ \\
\hline
\end{tabular}

\subsection{Measurements of the variables}

\section{- $\quad$ The variable to be explained}

To better specify our model, and due to the lack of a direct and reliable measure of our dependent variable, the variable of the quality of the joint audit is represented by the combination of the following four items; client's portfolio of each joint auditors, conservation of a work record that documents the work of each joint auditors, respect of ethical rules and the membership in an international network of each joint audit firm.

\section{- Explanatory variable}

In what follows, we will present the different explanatory variables of our model. The first variable, i.e. competence, is measured by 8 items developed by (Flint, 1988). The second variable, which focuses on ethical rules and professional due diligence, is measured by 9 items developed by (French national auditing body CNCC).The third variable, which revolves around independence, is measured by 4 items introduced by (Bennecib, 2004). The fourth variable, which is based on reputation, is measured by 3 items developed by (Kreps, 1990; St. Pierre \& Anderson, 1984)

Table 2- Definition and measurement of the explanatory variables

\begin{tabular}{llll}
\hline Variables & H & \multicolumn{1}{c}{ Measurements } & \multicolumn{1}{c}{ Authors } \\
\hline Competence & H1 & $\begin{array}{l}\text { Request, Board, Staff } \\
\text { qualification, ICT use },\end{array}$ & Flint, 1988; Manita and \\
& & Elommal 2010; Everaere, 2000; \\
& & Lee and Stone, 1995; Octaviaet \\
& specialization & Widodo, 2015; Bonner and \\
& & Lewis, 1990; Rusmanto, 2016; \\
& & Khaddash et al., 2013; Lobo et \\
& & al., 2017; Lesage et al.2017
\end{tabular}




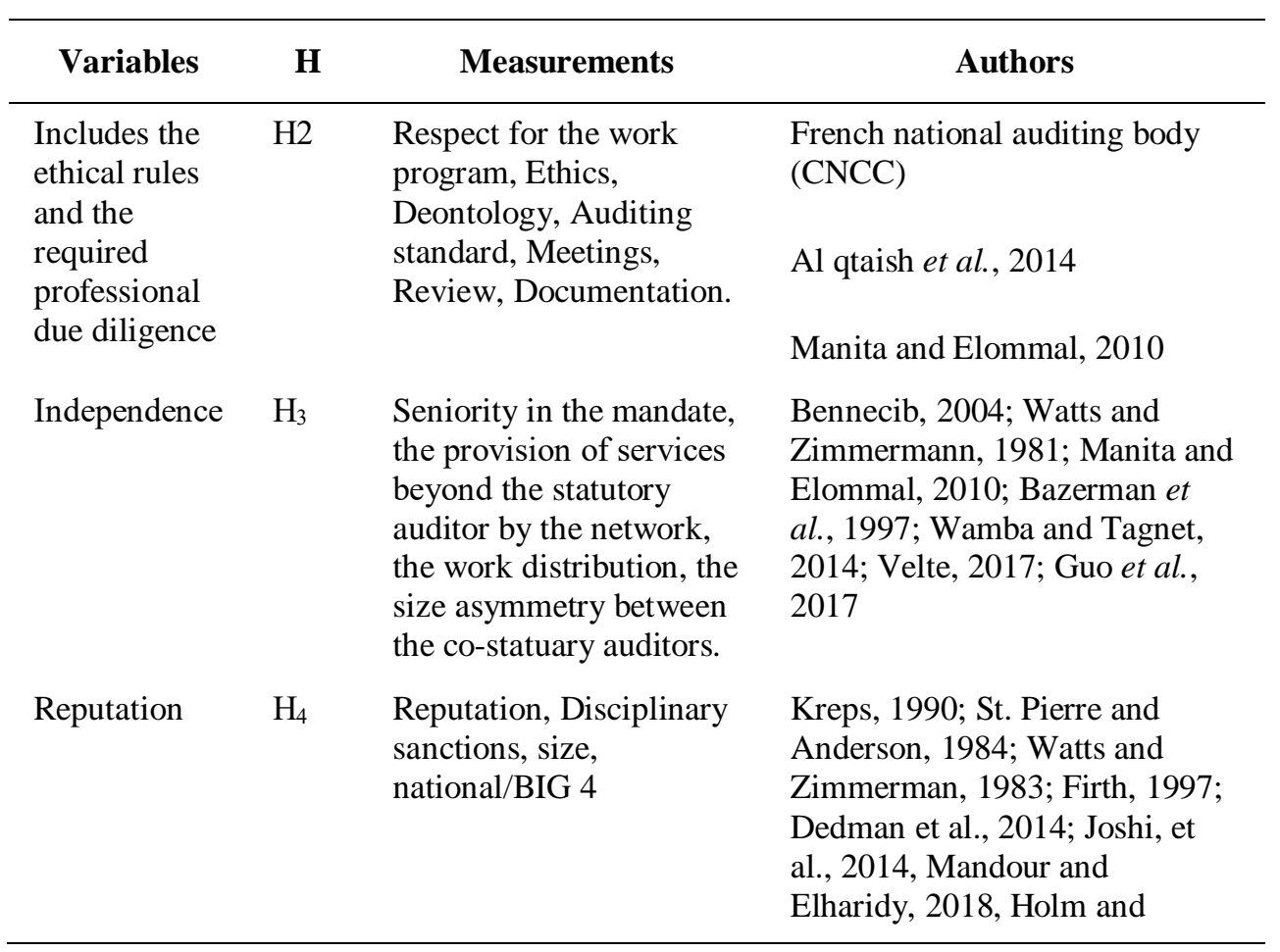

\subsection{Methods of data analysis}

The first step is that of the study of dimensionality of the scales and the purification of the measurement. A first principal component analysis (PCA) was conducted followed by a new principal component analysis on final data collection. The exploratory factorial analyses were carried out using the STATISTICA v11 software. They aimed at structuring the starting variables by grouping them into a smaller number of factors. Let us note that our scales are all a priori unidimensional.

\section{- $\quad$ Principal Component Analysis}

The PCA conducted in this step enabled us to promote the unidimensional character of our scales and identify the significant items that explain the variables to be subsequently used in our logistic regression model.

\section{- $\quad$ Logistic regression}

In what follows, we will try to analyze the correlations between the variables that are related to competence, ethical conduct and professional due diligence, independence, reputation, and quality of the joint audit using the Chi-square dependency test, which is based essentially on Chi-square statistics, as a bi-variate analytical method, which allows us to measure the intensity of the dependency existing between two variables. In fact, this test consists of formalizing the symmetrical hypothesis of independence 
called null and examining the result of the test on the basis of the Chi-square value, the degree of freedom and the probability of significance of the Chi-square. Therefore, under hypothesis $\mathrm{H} 0$, the probability of the significance of the Chi-square is low, i.e. lower than $10 \%$, whereas the alternative hypothesis corresponds to a high Chi-square value which indicates that there is a significant relationship between the involved variables.

Moreover, using a logistic regression for this model, we assume that companies are faced with one of the following two alternatives: either a good quality of the joint audit or a poor one. Therefore, using a binary response model (simple logit model), we try to explain the probability of achieving a good quality of the joint audit $(\mathrm{Y} * \mathrm{i})$ of 222 companies according to their determinants (Xi). More specifically, our research is intended to:

1. Analyze the determinants of the quality of the joint audit

2. Identify the different factors between "good" and "bad" quality of the joint audit;

3. Predicting the probability of a good quality of the joint audit.

However, since the $(\mathrm{Y} * \mathrm{i})$ variable to be explained is dichotomous, we are then in the presence of a simple logit (or dichotomous) model. Therefore, our modelling does not focus directly on the probability of achieving a good quality of the co-statutory auditors but on the logit of this probability. Consequently, the model to be estimated, which is the focus of our analysis, is presented as follows:

Quality*i $=\mathrm{b} 0+\mathrm{b} 1 *$ competencei $+\mathrm{b} 2 *$ compliance with ethical rulesi $+\mathrm{b} 3 *$ compliance with professional due diligencei $+\mathrm{b} 4 *$ independencei $+\mathrm{b} 5 *$ reputationi $+\mu \mathrm{i}$.

The $(\beta)$ coefficients was estimated using the logit model which describes the determining factors of the quality of the joint audit $\mu \mathrm{i}$ is iid $(0 . \sigma \mu \mathrm{i})$ where the reduced variable $\mu \mathrm{i} / \sigma \mu \mathrm{i}$ follows a law of the distribution function $\mathrm{f}(\mathrm{x})$, that is, identically independent and distributed. This econometric method was used by Reinke (1998). The $\beta 0$ parameter, (which is the constant) and the $\beta \mathrm{j}$ parameter (which is the slope of the coefficients of the explanatory variables) are determined using the maximum likelihood method in order to maximize the distinction between the different groups of companies. These parameters also indicate the variation of $y$ caused by a variation of xi for a unit, whereas the other explanatory variables are kept constant.

\section{Results and discussion}

\subsection{Descriptive analysis of the determinants of the joint audit quality}

We can also specify that if $62 \%$ of joint auditors have been mandated in the same firm more than once, $90 \%$ of joint auditors and their collaborators demonstrate their professional ethics. However, only one-third of them meet professional auditing 
standards. These rates are equal to $48 \%$ and $37 \%$ for banks and insurance companies, respectively. While more than half of the companies in our sample (54\%) tend to renew the mandate of joint auditors after its expiry, only $14.6 \%$ (4.6\% of the sample) of their joint auditors do not determine the organizational principles of their mission jointly. These results may seem satisfactory. Nevertheless, they demonstrate the degree of independence and the quality of the joint audit.

Furthermore, with regard to reputation, it can be noted that $82.6 \%$ of the firms of each of the co-auditors is one of the leading international firms. But the results are much lower with regard to disciplinary punishment since less than $1 / 8$ of the firms are not subject to these sanctions. More than two-thirds of the firms surveyed $(63.2 \%)$ set up continuing training programs. But only $22 \%$ of joint auditors make meetings between themselves and with management to close the mission. Almost all the firms of each of the joint auditors offer consulting services. Almost 2/3 of the client portfolios of each of joint auditors are high.

Finally, $98.2 \%$ of the joint auditors make use of information and telecommunication technologies. To better understand the influence of each factor on the quality of the joint audit, we carried out tests of comparing means. The variables were studied according to the quality of the mission "bad" and "good". Table 3 underlines the existence of a significant difference between the two types of mission quality with respect to the perception of each determinant.

Table 3. Descriptive analysis of the determinants of the joint audit quality

\begin{tabular}{|c|c|c|c|c|c|c|c|}
\hline & Mean & $\begin{array}{c}\text { St- } \\
\text { deviation }\end{array}$ & Minimum & Maximum & Skewness & Kurtosis & $\begin{array}{c}\text { Diff Mean } \\
\text { (p-value) }\end{array}$ \\
\hline $\begin{array}{l}\text { Respect of ethical } \\
\text { rules and due } \\
\text { diligence }\end{array}$ & 1.74 & 0.532 & 0.511 & 4.04 & 0.76 & 0.04 & $\begin{array}{c}0.3755 \\
(0.0000)\end{array}$ \\
\hline Independence & 0.747 & 0.2415 & 0.5142 & 3.048 & 0.86 & 0.12 & $\begin{array}{l}0.4480 \\
(0.000)\end{array}$ \\
\hline Reputation & 1.184 & 0.749 & 0.3652 & 3.485 & 1.76 & 0.05 & $\begin{array}{l}-0.2177 \\
(0.036)\end{array}$ \\
\hline Competence & 0.772 & 0.763 & 0.9255 & 3.074 & 0.54 & 0.47 & $\begin{array}{c}-0.4919 \\
(0.000)\end{array}$ \\
\hline
\end{tabular}

From the 6 items of the questionnaire, the factor analysis showed a one-factor solution which is in line with expectations, for a total explained variance of 59.3\%. Each of these items has at least a factorial weight of the order of 0.615. To confirm the homogeneity of each of these dimensions, we performed the alpha test which 
indicated that the reliability coefficient $\alpha$ was slightly greater than the selected threshold (0.76). Therefore, this scale is exploratory (Figure 2).

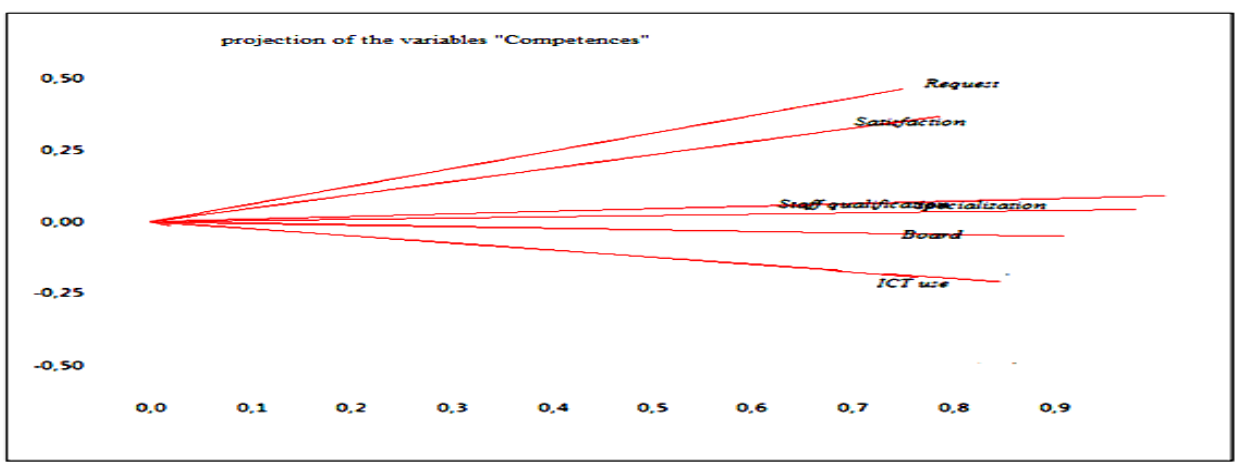

Figure 2. Presentation of items related to competence

The PCA enabled us to identify, from the 6 selected items, two factorial axes of competences which represent $65,8 \%$ of the total variance. The first factor, which defines compliance with the ethical rules, includes the following 5 items: "Respect for the work program ", Ethics", "Deontology ", "Auditing standard" and "Meetings". This axis accounts for $41.23 \%$ of total variance. However, the second factorial axis, which defines respect of the professional due diligence, explains $19.76 \%$ of the total variance, which brings together the items «Review» and «Documentation» (Figure 3).

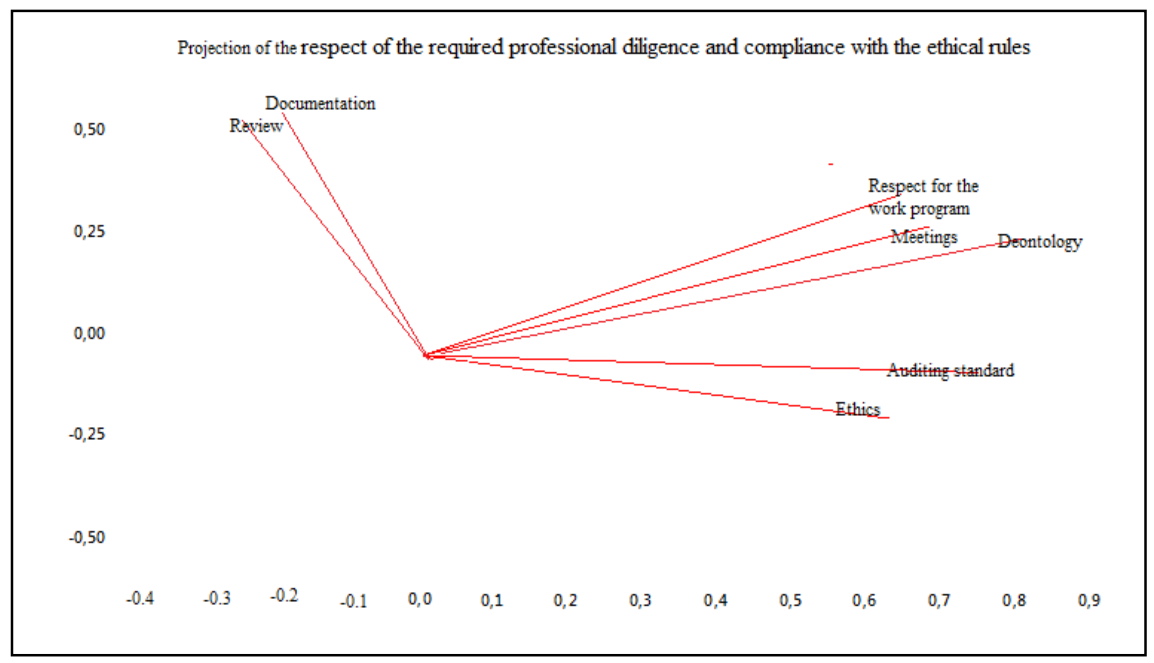

Figure 3. Presentation of the items respecting ethical rules and professional due diligence 
The results of the PCA highlight a uni-dimensional solution of the factors related to independence and reputation of each of the co-statuary auditors. Therefore, among the four items related to independence, the factorial analysis restores a unique factor for independence which accounts for $39.75 \%$ of the total variance and $55.68 \%$ of the total variance of reputation (Figure 4, Figure 5)

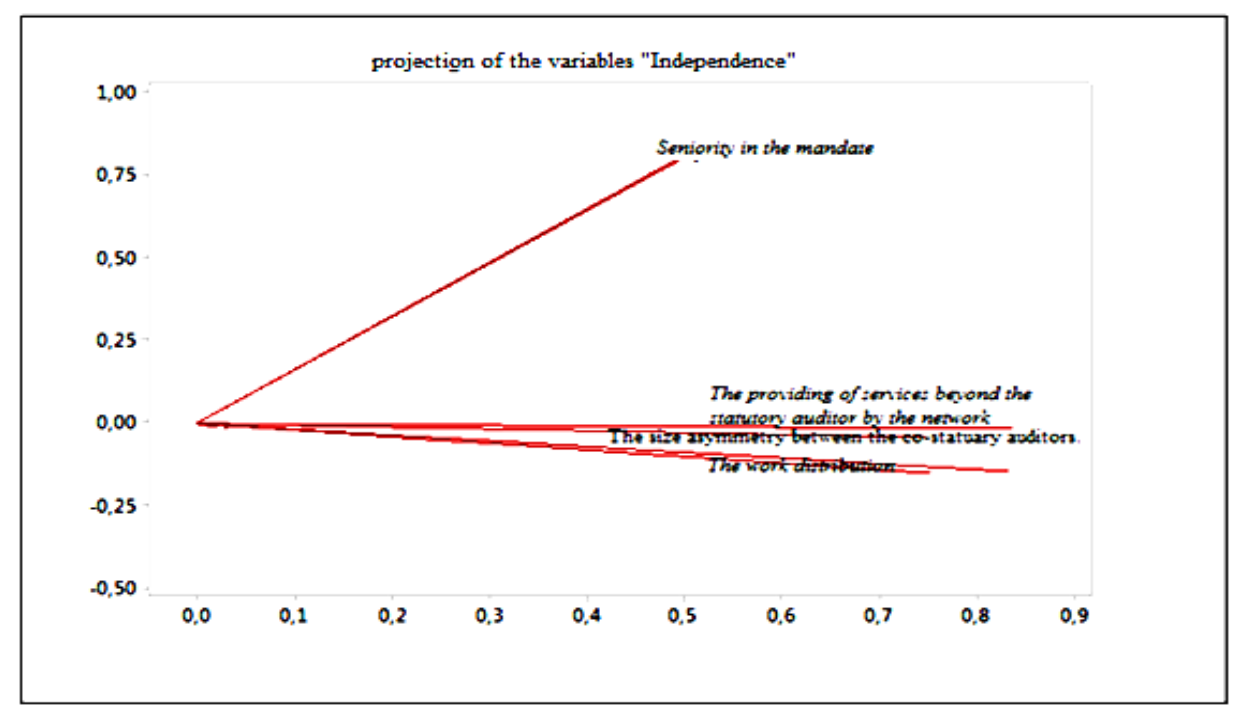

Figure 4. Presentation of items related to independence

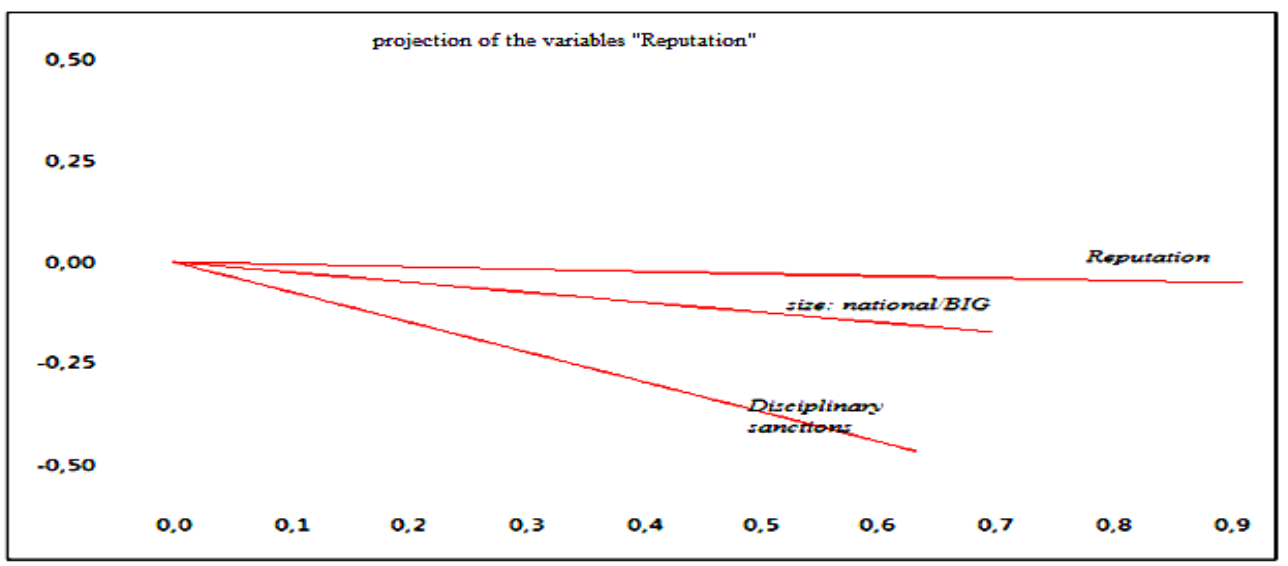

Figure 5. Presentation of items related to reputation 
To better understand the results of the PCA, we tried to analyze the reliability of our factors, using the coefficients of Cronbach $\alpha$ and the ( $\rho \mathrm{Gs}$ ) coefficient of Gutmann split. The choice of these two coefficients focuses particularly on the measurement of the internal coherence of a scale based on the correlation between these items. The only difference between these two coefficients is that the Gutmann index takes into account the error term.

Table 4. Indices of reliability and intra-item internal coherence

\begin{tabular}{ccc}
\hline Factors & $\alpha$ Cronbach & $\boldsymbol{\rho}_{\text {Gs }}$ Gutmann split \\
\hline $\begin{array}{c}\text { Competence } \\
\text { Compliance with the ethical } \\
\text { rules }\end{array}$ & 0.76 & 0.85 \\
& 0.658 & 0.774 \\
$\begin{array}{c}\text { Compliance with professional } \\
\text { due diligence }\end{array}$ & 0.548 & 0.588 \\
Independence & 0.784 & 0.71 \\
Reputation & 0.845 & 0.802 \\
\hline
\end{tabular}

Table 4 shows the reliability of the measurement scales. Furthermore, the items representing each determinant are convergent with an $\alpha$ Cronbach and a globally acceptable ( $\rho \mathrm{Gs})$ Gutmann split coefficient. Since these indicators are greater than 0.5 , our scales are considered to be reliable and satisfy all the criteria. From the point of view of internal coherence, all the items of each factor are convergent with a globally acceptable $\alpha$ Cronbach. Based on our previously analyzed exploratory framework, we put together the main factors that can lead to the mission quality of 222 co-statuary auditors. In fact, there was an emphasis on the following four determinants: "Competence", "Ethical Compliance and Professional due diligence", "Independence" and "Reputation". This observation was justified empirically. To this end, we relied on the Bivariate relationship that can exist between each factor and the quality of the joint audit using the chi-square test approach which helps analyze the existence or absence of a dependence between each factor and the quality of the joint audit.

This test is based essentially on the chi-square statistical test which enables us to measure the intensity of the dependence existing between two variables. Moreover, this test consists in formalizing the independence symmetric hypothesis called null hypothesis (H0) and examining the result of the test on the basis of chi-square statistical value, the degree of freedom and the probability of the chi-square significance. Under HO hypothesis, the chi-square significance probability is weak, 
i.e. lower than $10 \%$. Nevertheless, the alternative hypothesis corresponds to a high value of the chi-square, which indicates that there is a significant relationship between the involved variables.

Table 5. The dependence test results between the different factors specifying the quality of co-statuary auditor's job

\begin{tabular}{lccc}
\hline & Chi-square & $p$-value & degree of freedom \\
\hline Competence & 88.58 & 0.000 & 62 \\
Conformity with the ethical rules & 74.8 & 0.000 & 62 \\
$\begin{array}{l}\text { Conformity with professional } \\
\text { due diligence }\end{array}$ & 54.55 & 0.012 & 62 \\
$\begin{array}{l}\text { Independence } \\
\text { Reputation }\end{array}$ & 44.08 & 0.000 & 62 \\
\hline
\end{tabular}

(By the contingency table and under the chi-square statistics, we looked for the risk $\lambda$ corresponding to the chi-square table for the number that corresponds to degree of freedom $\mathrm{dl}=(\mathrm{N}-1) *(\mathrm{~N}-1)$. If $P<10 \%$, it indicates acceptance of the dependence hypothesis).

The Chi-square test shows the existence of a relationship between the co-statuary auditors' competences and mission quality. As a consequence, the hypothesis of no independence cannot be validated ( $p$-value $=0.0000)$. In other words, there is a significant relationship at a $1 \%$ threshold. These results emphasize the importance of the relative competence conceived by each of the co-statuary auditors to ensure a rational decision that depends only on the final objective of maximizing its usefulness in an environment characterized by risk and uncertainty and consequently by the quality of their mission. The test shows a chi-square equal to 14.05 , which is significant at a $1 \%$ threshold $(\mathrm{p}$-value $=0.000)$. These results show the compliance between the professional due diligence and the statuary auditors' mission quality. This implies that the alternative dependence hypothesis is accepted.

Therefore, the existence of a control system of professional due diligence affects the compliance with the statutory deadlines and the publication of accounts on one side and the expectations and the coordination to implement a common schedule of interviews on the other.

Our results also show the compliance between the ethical rules and the quality of the joint audit. Indeed, the test based on the chi-square statistics shows that the null hypothesis $\mathrm{H} 0$ ( $\mathrm{p}$-value $=0.83$ ) about the absence of significant dependence between these two last variables is accepted. We tested the model prediction quality to assess its ability to predict the values 0 and 1 of the quality of a co-statuary auditor's mission. At this level, a probability threshold equal to 0.5 is set. $\mathrm{H}_{0}$ : Quality $=1$ if Quality* $\geq 0.5$ and $\mathrm{H}_{1}$ : Quality $=0$ if Quality $*<0.5$ 
Under H0 hypothesis, the model can be specified with a predicted probability greater than the threshold, which means that the conceived missions of the joint auditors are of a good quality.

Table 6. Predictability and prediction of the logit model

\begin{tabular}{cc}
\hline \multicolumn{1}{c}{ Classification } & $\begin{array}{c}\text { Prediction } \\
\text { rate }\end{array}$ \\
\hline The good prediction rate of the joint auditor's good quality (quality=1) & $80.3 \%$ \\
The good prediction rate of the joint auditor's bad quality (quality=1) & $54 \%$ \\
\hline
\end{tabular}

As can be seen from table 5 regarding the good quality, 98 out of 122 cases were well predicted with a model prediction rate of $80.3 \%$. However, for the poor quality, a total of 54 out of 100 are well predicted at a rate of $54 \%$. To confirm the overall prediction quality of our model, the prediction rate is given as follows:

$$
\frac{98+54}{222}=68.5 \%
$$

These results emphasize the effectiveness of our model and the justified logistic regression choice.

Table 7. The estimation result: Logit model

\begin{tabular}{|c|c|c|c|}
\hline \multirow{2}{*}{ The determinants } & \multicolumn{2}{|c|}{ Joint effects } & \multirow{2}{*}{$\begin{array}{c}\text { Marginal effects } \\
\text { Coefficients }\end{array}$} \\
\hline & Coefficient & z-stat & \\
\hline competences & $4.142 * * *$ & 4.8 & 0.0298 \\
\hline $\begin{array}{l}\text { Compliance with the ethical } \\
\text { rules }\end{array}$ & $2.332 * * *$ & 2.69 & 0.089 \\
\hline $\begin{array}{l}\text { Compliance with the } \\
\text { professional due diligence }\end{array}$ & 0.325 & 0.22 & 0.004 \\
\hline Independence & $3.18 * * *$ & 2.98 & 0.0662 \\
\hline Reputation & $1.83^{*}$ & 1.72 & 0.0477 \\
\hline constant & $9.9847 * * *$ & 6.89 & 0.0774 \\
\hline $\begin{array}{l}\text { Log likelihood } 2245.235 \\
\text { Chow Test: } 1.024\end{array}$ & $\begin{array}{l}\text { Chi-square: } 17 . \\
\text { (p-value }):(0\end{array}$ & $\begin{array}{l}4 \quad p \text {-value } \\
1287)^{p}\end{array}$ & $0.000) \mathrm{R}^{2}: 40.28 \%$ \\
\hline
\end{tabular}


From the table, the overall Chi-square significance test shows that the model is globally significant $(p$-value $=0.0000)$. The chow test confirms the absence of an intra-group difference and hence the stability of the coefficients between the two groups of firms.

The estimations shown by the above table emphasize the crucial role played by the four factors in the explanation of the quality of the joint audit. Empirically, this idea is consolidated by the presence of a moderately high determination coefficient (R2 $=0.4 \mathrm{O}$ ). Therefore, it can be said that this percentage is sufficient for the explanation of the qualitative variable and of the good adjustment quality.

The analysis of the relationship between the competence of each of the joint auditors and his own mission quality is statistically significant at $1 \%$ level and carries a positive sign (4.142).Indeed, a 1\% increase in competence based on the consulting services, offered by staff qualification and the use of ICTs, lead to an increase by $4 \%$ in the probability that each co-statutory auditor is of good quality. This result is consistent with the result of Baldauf and Steckel (2012). Thus, we can conclude that $\mathrm{H} 1$ is validated.

Another important factor relative to compliance with the ethical rules shows that a $1 \%$ increase of the compliance with diligence implies a rise by 2.3 points of the probability that each joint auditor must be of good quality at a $1 \%$ threshold. This last result is in line with the result of $\mathrm{Al}$ qtaish et al. (2014).

The results invalidate the hypothesis that the formalization of a regulatory system in terms of diligence positively and significantly affects the quality of the joint audit. This result is contrary to that found by Manita and Elommal (2010). Since ethical rules have a significant effect on the joint audit and diligence and not on the quality, we can conclude that $\mathrm{H} 2$ is partially validated.

In addition, our results show a positive and significant effect of independence on the quality of the joint audit. The $10 \%$ increase in independence generates an increase of $3 \%$ in the probability that each of joint audit is of good quality (at the $1 \%$ level). This result is consistent with the result of Khatab (2013).Therefore, H3 is validated.

However, our results show the significance of the impact of independence on the quality of the joint audit. Finally, the hypothesis that reputation affects the quality of the joint audit is validated. In fact, our findings show that the coefficient associated with the 'reputation' variable is statistically significant at a threshold of $1 \%$ with a positive sign, suggesting a positive relationship as expected. This finding coincides with the result of Krishnamurthy et al. (2003) and hence H4 is validated.

To better justify the choice of the logit model, we proposed an approximate value of the realization of the various estimators of the explanatory variables in the case of a 
probit model with a simple model of our study. It is the most probabilistic model that better tests the significance of the joint effects of the explanatory variables and also the probability to accept the hypothesis of non-nullity. For this purpose, it can be noted that:

Linear $B$ : The estimator in a linear model

Probit $B$ : The estimator in a probit model

Table 8. The selection criterion of the logit model

\begin{tabular}{lcc}
\hline \multicolumn{1}{c}{ Variables } & $\begin{array}{c}\text { Estimation through the } \\
\text { linear model }\left(\mathbf{B}_{\text {linear }}=\right. \\
\left.\mathbf{0 . 2 5 2 B} \mathbf{B}_{\text {Logit }}\right)\end{array}$ & $\begin{array}{c}\text { Estimation through } \\
\text { the probit model } \\
\left(\mathbf{B}_{\text {probit }}=\mathbf{0 . 6 3 B} \text { Logit }\right.\end{array}$ \\
\hline competence & 0.054 & 0.401 \\
ethical rules & 0.847 & -1.415 \\
diligence & 0.299 & 2.041 \\
Reputation & 0.325 & 0.411 \\
\hline
\end{tabular}

Our results confirm the predictive capability of the logit model compared to both the linear and probit models and reveal that the last two are biased and not convergent. This choice is determined on the basis of the estimated coefficients of the different significant factors and also according to a probabilistic procedure which clearly sets out the non-linearity that must be estimated by the method of maximum likelihood as an adjustment measure and penalize the introduction of additional parameters. At this level, table 8 shows that the logit model is the most appropriate to better specify our model. The table below shows the results of our assumptions.

Table 9. The results of the hypotheses

\begin{tabular}{llll}
\hline \multicolumn{1}{c}{ Hypotheses } & Expected sign & Sign & $\begin{array}{c}\text { Confirmed / } \\
\text { overturned }\end{array}$ \\
\hline H1: competence & + & + & $\begin{array}{l}\text { Confirmed } \\
\text { H2: Compliance with the ethical rul the }\end{array}$ \\
professional due diligence & + & + & Partially validated \\
H3: Independence & + & & \\
H4: Reputation & + & + & Confirmed \\
\hline
\end{tabular}

Hypotheses H1, H3 and H4, dealing with competences, independence and reputation, are confirmed. Hovewer, hypothesis $\mathrm{H} 2$ is partially validated.

\section{Conclusion, limitations and further research}

This study emphasizes the participation of several factors in enhancing the quality of the joint audit. According to the predictive results of our model, it seems that the 
quality of the joint audit contributes to the prediction of four factors that significantly affect it, namely competence (which increases the probability of achieving quality by 4points), compliance with ethical rules (which increases the probability of achieving quality by 2 points), reputation (which increases the probability of achieving quality by 2 points) and independence (which increases the probability of achieving quality by 3 points).

On the basis of these findings, the three previously mentioned factors explain 40.28 of the variance of the co-statuary auditor's quality which is quite high. Our results show the absence of a significant and positive relationship between compliance with the professional due diligence and quality mainly because of the choice of the selected items. Therefore, other items would improve compliance with this factor.

Nevertheless, our research has some limitations. A first limitation is related to the small size of our sample. Furthermore, the reached contextual results cannot be generalized because of the specificity of the Tunisian context. The third limitation relates to the imbalance in the level of the composition of our sample and sectors, which requires the neutralization of the effect of this imbalance. In short, new research avenues can be tracked in order to extend our research and findings. It is worth making a comparison between the results found in this research and those found in other similar studies conducted before the Tunisian revolution and also limiting the analysis to a special class of businesses to avoid sector effect and draw more reliable conclusions.

\section{References}

Abdel-khalik, A.R (1990) "The jointness of audit fees and demand for MAS a selfselection analysis", Contemporary Accounting Research, vol. 6, no. 2: 295-322

Alfraih, M. A. (2016) "Corporate governance mechanisms and audit delay in a joint audit regulation", Journal of Financial Regulation and Compliance, vol. 24 no. 3:292-316

Al-Hadi, A., Habib, A., Al-Yahyaee, K. \& Eulaiwi, B. (2017) "Joint audit, political connections and cost of debt capital", International Journal of Auditing, vol. 21, no.3: 249-270

$\mathrm{Al}$ qtaish,H.F., Mohammad Baker,A.\& Othman,O.H. (2014) "The ethical rules of auditing and the impact of compliance with the ethical rules on auditing quality", International Journal of Research and Reviews in Applied Sciences, vol. 18, no.3: 248-262

André, P., Broye, G., Pong, C. \&Schatt, A. (2015) “Are joint audits associated with higher audit fees?" European Accounting Review, vol. 25, no. 1: 245-274.

Andrè, P., Broye, G., Pong, C. \&Schatt, A. (2009) "Audit fees, big four premium and institutional settings: The devil is in the details!", available at http://ssrn.com/abstract 
Baker, T.L. (1994) Doing Social Research (2nd Edn.), New York: McGraw-Hill Inc.

Baldauf, J. \& Steckel, R. (2012) "Joint audit and accuracy of the auditor's report: an empirical study", International Journal of Economic Sciences and Applied Research, vol. 5, no.2: 7-42

Bazerman, M. H., Morgan, K. P., \& Loewenstein, G. F. (1997) "The impossibility of auditor independence", Sloan Management Review, vol.34, no. 4: 89-94

Bennecib F. (2004) "De l'efficacité du co-commissariat aux comptes", Thèse Université Paris Dauphine

Bianchi, P.A, Falsetta, D., Minutti-Meza, M., \&Weisbrod, E. (2019) "Joint audit engagements and client tax avoidance: evidence from the Italian statutory audit regime", The Journal of the American Taxation Association, vol. 41, no. $1: 31-58$

Bisogno, M. \& De Luca, R. (2016), "Voluntary joint audit and earnings quality: evidence from Italian SMEs", International Journal of Business Research and Development, vol.5, no.1: 1-22

Bonner S. \& Lewis B. (1990) "Determinants of auditor expertise", Journal of Accounting Research, vol.28: 1-28

Brahima, O.M.A. \& Abdelkadera, B,A.N.(2014) "Les facteurs d'influence de l'indépendance de l'auditeur externe: une étude exploratoire auprès des préparateurs de l'information financière tunisiens", La Revue Gestion et Organisation, vol.6, no.2:67-74

Carcello, J.V. \&Nagy, A.L. (2004) "Audit firm tenure and fraudulent financial reporting", Auditing: A Journal of Practice \& Theory, vol.23, no.2: 55-69

Carey, P. \& Simnett,R. (2006) "Audit partner tenure and audit quality", The Accounting Review, vol.81, no.3: 653-76

Charreaux, G. (2000) "La théorie positive de l'agence : positionnement et apports", Revue d'économie industrielle, vol. 92, no.1:193-214

Craswell, A. T., J. R. Francis, \&S. L. Taylor. (1995) "Auditor brand name reputations and industry specializations", Journal of Accounting and Economics, vol. 20, no. 3: 297-322

De Angelo, L. (1981) "Auditor size and quality", Journal of Accounting and Economics, vol. 3, no. 3: 183-199

Dedman, E., Kausar, A. \&Lennox, C.S. (2014) "The demand for audit in private firms: recent large-sample evidence from the UK", European Accounting Review, vol.3, no.1:1-23

DeFond, M.L. \& Jiambalvo, J. (1993) "Factors related to auditor-client disaggrements over income-increasing accounting methods", Contemporary Accounting Research, vol. 9, no. 2: 415-431

Deng, M.,Lu, T., Simunic, D. A. \&Ye, M. (2012) "Do joint audits improve or impair audit quality", Journal of Accounting Research, vol. 52, no. 5: 1029-1060

Everaere C. (2000) "La compétence : un compromis multidimensionnel fragile", Gestion 2000, n4, juillet et août: 53-71 
Firth, M. (1997) "The provision of non-audit services and the pricing of audit fees", Journal of Business Finance and Accounting, vol. 24, no.3: 511-525

Flint D. (1988) Philosophy and principle of auditing, Basingstoke: Macmillan Education.

Francis, J. R., Vanstraelen, A. \&Richard, C. (2009) “Assessing France's joint audit requirement: Are two heads better than one?", Auditing: A Journal of Practice \& Theory, vol. 28, no. 2: 35-63

Green, D. L. (2006) "Auditor independence in Canada: A historical perspective from shareholder auditors to modern-day audit committees", Canadian Accounting Perspectives, vol. 5, no.1:37-65

Guo, Q., Koch, C. \& Zhu,A. (2017) "Joint audit, audit market structure, and consumer surplus", Review of Accounting Studies, vol. 22, no. 4: 1595-1627

Haak, M.Muraz, M. \& Zieseniß,R. (2018) "joint audits: does the allocation of audit work affect audit quality and audit fees?", Accounting in Europe, vol. 15, no. $1: 55-80$

Hogan, C.E. \& Jeter, D.C. (1999) "Industry specialization by auditors", Auditing: A Journal of Practice \& Theory, vol. 18:1-17

Holm, C. \& Thinggaard, F. (2016) "Paying for joint or single audits? the importance of auditor pairings and differences in technology efficiency", International Journal of Auditing, vol. 20, no. 1:1-16

Holm, C., \&Thinggaard, F. (2014) "Leaving a joint audit system: conditional fee reductions."Managerial Auditing Journal, vol.29, no.2: 131-152.

Holm, C. \&Thinggaard, F. (2017) "From joint to single audits - audit quality differences and auditor", Accounting and Business Research, vol. 48: 321-344

Ittonen, K. \&Trønnes,P. (2015) "Benefits and costs of appointing joint audit engagement partners", Auditing: A Journal of Practice \& Theory, vol.34, no. $3: 23-46$

Jane Lin, C., Lun Lin, H. \& Yen, A. (2014) "Dual audit, audit firm independence, and auditor conservatism", Review of Accounting and Finance, vol. 13, no. 1 : $65-87$

Joshi, p.L., Deshmukh, A., NikSalleh,A.N.M.Z \& Jaffar, N. (2014) "Study", International Journal of Strategic Decision Sciences, vol.5, no.4 :79-98

Kermiche, L. \& Piot, C. (2016) "The audit market dynamics in a mandatory joint audit setting - the French experience", Journal of Accounting, Auditing \& Finance, vol. 31: 1-22

Khaddash, H.A., Nawas, R.A. \&Ramadan, A. (2013) "Factors affecting the quality of Auditing: The Case of Jordanian Commercial Banks", International Journal of Business and Social Science, vol.4, no.11:206-222

Khatab, G. S. (2013) "The effect of joint audit and audit rotation on the firm's value", International Business Research Conference, available at: http://wbiworldconpro.com/uploads/melbourne-conference-2013

Koh H. C. \&Mahathevan P. (1993) "The effects of client employment on auditor independence", The British Accounting Review, vol. 25, no. 3: 227-242 
Kreps, D. M. (1990) "Corporate Culture and Economic Theory", in J. E. Alt and K. A. Shepsle (eds), Perspectives on Positive Political Economy, Cambridge, England: Cambridge University Press

Krishnamurthy S., Zhou, J. \& Zhou, N. (2003) "Auditor reputation, auditor independence \&stock market reaction to Anderson's clients", working paper: Binghamton University

Kwon, S.y., Lim, Y. \&Simnett, R. (2014) "The effect of mandatory audit firm rotation on audit quality and audit fees: empirical evidence from the Korean audit market", Auditing: A Journal of Practice \& Theory,vol. 33, no.4: $167-196$

Lee T. \& Stone, M. (1995) "Competence of a independence: the congenial twins of auditing", Journal of Business, Finance and Accounting, vol. 22, no. 8: $1169-1177$

Lesage C., Ratzinger-Sakel N.V.S. \& Kettunen J. (2017) "Consequences of the abandonment of mandatory joint audit: an empirical study of audit costs and audit quality effects", European Accounting Review, vol. 26, no. 2: 1-29

Lew, B. \& Richardson, A. J. (1992) "Institutional responses to bank failure: A comparative case study of the home bank (1923) and Canadian commercial bank (1985) failures", Critical Perspectives on Accounting, vol. 3, no. 2: $163-183$

Lin, T.W., Yang, D.C. \& Hartwell, C.L. (1993) "How internal auditors use microcomputers in practice", Internal Auditing, Hiver: 24-32

Lobo, G., Paugam, L., Zhang, L., \& Casta, J. (2013) "Effect of joint auditor pair on conservatism: evidence from impairment tests", Comptabilité sans Frontières, available at: https://halshs.archives-ouvertes.fr/hal00993007/document

Lobo, G.J., Paugam, L., Zhang, D \& Casta, J.F. (2017) "the effect of joint auditor pair composition on audit quality: evidence from impairment tests", Contemporary Accounting Research, vol.34, no.1: 118-153

El Assy, M.G. (2015) "The effect of joint audit on audit quality: empirical evidence from companies listed on the Egyptian stock exchange", International Journal of Accounting and Financial Reporting, vol. 5, no. 2:195-207

Mandour, A.M. \& Mokhtar, E.S. (2018) "Examining the effect of joint and dual audits on earnings management practices", International Journal of Accounting and Financial Reporting, vol.8, no.1: 84-114.

Manita, R. \& Elommal, N. (2010) "The quality of audit process: an empirical study with audit committees", International Journal of Business, vol. 15, no.1: 87-99

Marmousez, S. (2012) "Examining a French exception: The determinants of the choice of joint-auditors", Comptabilité Contrôle Audit, vol. 18, no. 1: 121-151

Mautz, R.K. \& Sharaf, H.A. (1961) "The philosophy of auditing, monograph n6", American Accounting Association, Florida 
Mazars (2010) "Contribution to the Green Paper published by the EU Commission". Available at: http://www.mazars.fr/mazarspage/download/54034/1299441 /version/2/file/GreenPaper_EN.pd

Mousa, R.M. (2015) "Evaluating the Independence of the Internal Auditor: The Case Study of Al-Bariga Oil Marketing Company", Proceedings of 22nd International Business Research Conference Melia Galgos Hotel, Madrid, Spain, 9:1-20

Naslmosavi, S., Sofian, S. \& Saat, M.B.M. (2013) "The effect of audit firm size on independent auditor's opinion", Conceptual Framework: 243-248

Neveling, N. (2007) "French CFO attacks joint audit", Accountancy Age: 4-4

Octavia, E. \& Widodo, N.R. (2015) "The effect of competence and independence of auditors on the audit quality", Research Journal of Finance and Accounting, vol.6, no.3: 189-194

Okaro, S.O., Okafor, G. O. \& Ofoegbu, G. N. (2018) "Mandating joint audit in Nigeria: Perspectives and issues", International Journal of Academic Research in Business \& Social Sciences, vol.8, no.3: 316-338

Razinger-Sakel, N., Audosset-Coulier, S., Kettumen, J. \& Lessage, C. (2013) “Joint audit issues and challenges for researchers and policy makers", Accounting in Europe, vol.10, no.2: 175-199

Read, W.J. (2015) "Auditor fees and going-concern reporting decisions on bankrupt companies: additional evidence", Current Issues in Auditing, vol. 9, no. $1: 13-27$

Reinke, J. (1998) "How to lend like mad and make a profit: a micro-credit paradigm versus the start-up in South Africa", Journal of Development Studies, vol. 34 , no. 3 : $44-61$

Richard, C. (2000) 'Contribution à l'analyse de la qualité du processus d'audit: le rôle de la relation entre le directeur financier et le commissaire aux comptes", Thèse pour le doctorat ès sciences de gestion, université de Montpellier II

Rusmanto, T, (2016) "Do audit firm size and their services matter on auditor independence: A Case of Indonesia", Journal of Business Studies Quarterly, vol. 7, no. 3:1-17

Skinner, D.,J. \& Srinivasan, S. (2012) "Audit quality and auditor reputation: Evidence from Japan”, The Accounting Review, vol. 87, no. 5:1737-1765

St. Pierre, K., \&J. Anderson. (1984) "An analysis of the factors associated with lawsuits against public accountants", The Accounting Review, vol. 59, no. 2:242-263

Velte, P., \& Azibi, J. (2015) “Are joint audits a proper instrument for increased audit quality?", Journal of Applied Science and Technology, vol.7: 528-551.

Velte, P. (2017) "What do we know about empirical joint audit research? A literature review", Accounting and Financial Control, vol.1, no.1:4-14

Wamba, L, D. \& Tagne, A.G.F (2014) “ Le comportement des audités: quel effet sur la qualité de service rendu par les cabinets d'audit au Cameroun? ", La Revue Gestion et Organisation, vol.6, no.2 : 93-103 
Watts R. \& Zimmermann J., (1981) "Auditors and determination of accounting standards", Working 54 Paper, University of Rochester

Watts, R. \& Zimmerman, J. (1983) "Agency problems, auditing and the theory of the firm some evidence", Journal of Law and Economics, vol. 26, no. 3: $613-633$

Wines, G. (1994) "Auditor independence, audit qualifications and the provision of non-audit services: A note", Accounting and Finance: 75-86

Yaşar, A.(2013) "Big Four Auditors' audit quality and earnings management: Evidence from 7 Turkish Stock Market", International Journal of Business and Social Science, vol. 4, no. 17: 153-163

Zerni, M., Haapamäki, E., Järvinen, T., \& Niemi, L. (2012) "Do joint audits improve audit quality? Evidence from voluntary joint audits", European Accounting Review, vol. 21, no. 4: 731-765 